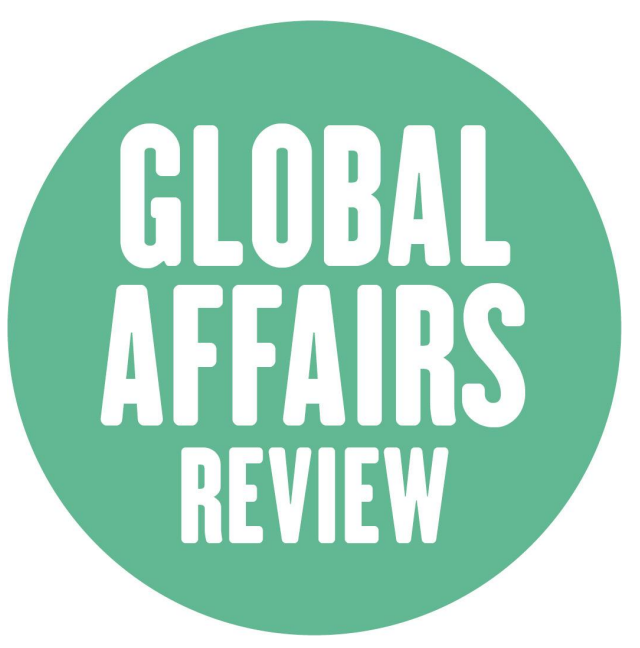

Fuzzy Signals to Potential Observer States in the Arctic Council Alexandra Middleton

Global Affairs Review, Vol. 2, No. 2

Fall/Winter 2021 


\section{Fuzzy Signals to Potential Observer States in the Arctic Council}

Alexandra Middleton

To cite this article: Alexandra Middleton, Fuzzy Signals to Potential Observer States in the Arctic Council, Global Affairs Review, Vol. 2, No. 2, Fall/Winter 2021.

doi:

ISSN (online): 2660-6968

Global Affairs Review Website: https://www.globalaffairreview.org/

Published online: December, 2021 


\begin{abstract}
The attention to the Arctic is fuelled by the prospect of economic development, emerging shipping routes, and changing geopolitics. Since 1996 the Arctic Council, an intergovernmental forum for Arctic cooperation, has served to foster environmental protection and sustainable development in the region. The Arctic Council is composed of the eight Arctic states with territory north of the Arctic Circle and six Permanent Participants representing Arctic Indigenous People. Since its inception, the Arctic Council has admitted 13 non-Arctic Observer states. However, in 2021 three new candidates (Ireland, Czech Republic, and Estonia) were not successful with their applications despite proven records of Arctic research and influence in the region. This article will elaborate on the dynamics of Observer states admittance to the Arctic Council. Signalling theory is applied in this paper as a theoretical lens. More precisely, this paper will concentrate on fuzzy signalling, because such signals do not fall into binary classification and require a lot of contextual geopolitical information for interpretation. The data consists of research articles, publicly available statements, and media articles. The findings demonstrate that the admittance of Observer states to the Arctic Council can be viewed as fuzzy signalling. This paper will argue that fuzzy signalling is intrinsic to a multi-actor governance forum like the Arctic Council, where decisions are made on a consensus basis.
\end{abstract}


The promise of economic development in the Arctic, the emergence of new shipping routes, and the shifting geopolitical landscape are all driving interest in the region. The Arctic region has been attracting attention as an arena for geopolitical competition between the United States, Russia, and China. At the same time, the region has been marked by international cooperation since the 1990s. The main player for international cooperation is the Arctic Council, established in 1996 as an intergovernmental forum involving all eight Arctic States (Canada, USA, Russia, Iceland, Denmark (via Greenland), Finland, Norway, and Sweden). The Arctic Council has two objectives: environmental protection, and sustainable development. Despite this face value consensus, Arctic policy issues are often framed in competitive and controversial terms, the simultaneous performance of both cooperation and rivalry amongst the states in the Arctic region. ${ }^{1}$ This is exacerbated especially when non-Arctic states' interests in the region are drawn to the picture. ${ }^{2}$

Since its inception, the Arctic Council has been open to non-Arctic Observer states. As of 2021, the Arctic Council has admitted 13 Observer states. Non-Arctic states seek Observer status to increase their political engagement with the larger Arctic region in order to secure a space in Arctic regional governance. Furthermore, non-Arctic states exert effort to obtain legitimacy toward the region. ${ }^{3}$

This paper studies how non-Arctic Observer states have been accepted into the Arctic Council from the start of its functioning until the present. The data consists of research articles,

\footnotetext{
${ }^{1}$ Elana Wilson Rowe, "Analyzing frenemies: An Arctic repertoire of cooperation and rivalry," Political Geography 76 (2020), https://doi.org/10.1016/j.polgeo.2019.102072.

${ }^{2}$ Aslak Veierud Busch, "Tall Tales from the High North: Contested Discourses of the Arctic as a Political Space.” Geopolitics (2021): 1-27, https://doi.org/10.1080/14650045.2021.1963956.

${ }^{3}$ Vesa Väätänen and Kaj Zimmerbauer. "Territory-network interplay in the co-constitution of the Arctic and 'to-be'Arctic states," Territory, Politics, Governance 8, no. 3 (2020): 372-389, https://doi.org/10.1080/21622671.2018.1559759.
} 
publicly available statements, and media articles. This paper will examine the admittance of Observer states to the Arctic Council through the application of signalling theory. Specifically concentrating on fuzzy signalling, because such signals do not fall into binary classification and require a lot of contextual geopolitical information for interpretation.

Signalling is the means of conveying information by various actions or signals. In international relations signalling has been used to study alliance commitments. ${ }^{4}$ Acceptance or non-acceptance of non-Arctic Observer states to the Arctic Council can be viewed as a specific implementation policy that the constituents of the Arctic Council (AC) use to signal their commitments and long-ranging intentions. Following growing interest in gaining Observer status, the AC made significant progress during the 2011 ministerial meeting in Nuuk, Greenland when it released admission criteria for Observers and a definition of their subsequent roles. ${ }^{5}$ In 2013, Erik Solli, Elana Wilson Rowe, and Wrenn Yennie Lindgren ${ }^{6}$ conducted interviews with informed sources. They concluded from these informant interviews that both Canada and Russia remain reluctant to permit new Observers, and comment that both countries were the primary supporters of the Observer Manual introduced in 2013. Meanwhile the Nordic States and the US have adopted a more inclusive Observer strategy.

This paper will further analyze the stages and processes of non-Arctic states admittance as Observers to the Arctic Council by examining documents and studies related to these stages

\footnotetext{
${ }^{4}$ Matthew Fuhrmann and S. Sechser Todd, "Signaling Alliance Commitments: Hand-Tying and Sunk Costs in Extended Nuclear Deterrence," American Journal of Political Science 58, no. 4 (2014): 919-35, https://www.jstor.org/stable/24363534.

${ }^{5}$ Piotr Graczyk and Timo Koivurova, "A new era in the Arctic Council's external relations? Broader consequences of the Nuuk observer rules for Arctic governance,” Polar Record 50, no. 3 (2014): 225-236, https://doi.org/10.1017/S0032247412000824.

${ }^{6}$ Per Erik Solli,, Elana Wilson Rowe, and Wrenn Yennie Lindgren. “Coming into the Cold: Asia's Arctic Interests." Polar Geography 36, no. 4 (December 1, 2013): 253-70, https://doi.org/10.1080/1088937X.2013.825345.
} 
and processes. This is important for understanding how open the Arctic Council to new non-Arctic Observer states.

\section{Signalling Theory}

Signalling is conveying information by means of actions or signals. Signalling, as part of the international relations scholarship, studies how uncertainty can be reduced. Within an anarchic international system, governments can never be certain of their adversaries' intentions; they lack access to their adversaries' true motivations and the true purpose of their actions. ${ }^{7}$ This results in two 'lemmas': ambiguity over how to interpret signals provided by other states - is a military buildup aggressive or defensive $?^{8}$ - and subsequent doubt regarding how to respond. ${ }^{9}$ Thus, the security challenge is centered on information flows and a lack of comprehension nations lack knowledge that can reliably inform them of the intentions of others. Signalling is vital in non-zero-sum interactions like chicken (e.g., nuclear deterrence) and the prisoner's dilemma (e.g., tariff reductions). ${ }^{10}$

In order for the signal to count it needs to be costly. National leaders have access to confidential information on their countries' varied qualities. They possess private information on the nation's political stability, as well as private information about the tastes and values of their citizens. While other nations can acquire part of this knowledge through regular encounters, observation, study, and espionage, history demonstrates that cultural barriers are difficult to

\footnotetext{
${ }^{7}$ Daniel R. McCarthy and Matthew Fluck, "The concept of transparency in International Relations: Towards a critical approach," European Journal of International Relations 23, no. 2 (2017): 416-440. https://journals.sagepub.com/doi/10.1177/1354066116651688.

${ }^{8}$ Robert Jervis, "Perception and misperception in international politics," (Princeton University Press, 2017).

${ }^{9}$ Nicholas Wheeler and Ken Booth, "The security dilemma: Fear, cooperation, and trust in world politics," (Palgrave Macmillan, 2008).

${ }^{10}$ Erik A Gartzke, Shannon Carcelli, J. Andres Gannon, and Jiakun Jack Zhang, "Signaling in foreign policy," In Oxford Research Encyclopedia of Politics, 2017.
} 
overcome and reciprocal ignorance is prevalent. ${ }^{11}$ The most common costly signals are sinking costs and tying hands. Leaders may either incur sinking costs by taking ex-ante financially costly actions such as mobilizing troops or tie their hands by creating audience costs that they will incur ex-post if they do not carry out their threat or commitment (i.e., costs resulting from the actions of domestic political audiences). Research demonstrates that leaders never bluff with either form of signal in the games' equilibria; they do not incur or produce costs and then fail to respond when challenged. ${ }^{12}$

Signalling in dyadic country relations is well researched. ${ }^{13}$ The complexity comes from interpreting and understanding signals in new governance models characterized by the emergence of new types of agency and actors in addition to national governments. The emergence of new global governance mechanisms and institutions that go beyond traditional state-led, treaty-based regimes, like the Arctic Council, creates ambiguity in interpreting the signals. ${ }^{14}$ To an outsider it may be unclear why some countries that follow the set of rules and fulfill criteria to obtain Observer status are not accepted. The signals produced by the Arctic Council can be considered fuzzy because they do not fall into binary classification and require a lot of contextual geopolitical information for interpretation, which is still incomplete and imprecise as compared to the insider information.

\footnotetext{
${ }^{11}$ Jack L Goldsmith and Eric A. Posner, "Moral and legal rhetoric in international relations: a rational choice perspective," The Journal of Legal Studies 31, no. S1 (2002): S115-S139, https://doi.org/10.1086/340087.

12 James D Fearon, "Signaling foreign policy interests: Tying hands versus sinking costs," Journal of Conflict Resolution 41, no. 1 (1997): 68-90, https://doi.org/10.1177/0022002797041001004.

${ }^{13}$ See note 9.

${ }^{14}$ Frank Biermann and Philipp Pattberg, “Global environmental governance: Taking stock, moving forward," Annual Review of Environment and Resources 33 (2008): 277-294, https://doi.org/10.1146/annurev.environ.33.050707.085733.
} 


\section{Arctic Cooperation and the Arctic Council}

In 1991 the need for environmental protection of the Arctic resulted in the Arctic Environmental Protection Strategy (AEPS), an initiative by the Arctic states. Moreover, the AEPS aimed to develop multilateral responses to Russian Arctic pollution. ${ }^{15}$ In 1991, the AEPS was signed by the Ministers responsible for Arctic environmental issues of all the Arctic countries in Rovaniemi, Finland. This was the foundation for what became the Arctic Council, created in 1996 by the Ottawa Declaration. The Arctic Council is not an international organization, but a non-decision-making and consensus-based institution falling under soft-law without regulatory authority. ${ }^{16}$ All Arctic states sought to ensure that Arctic developments were driven by national government interests, which served as a motive for attaining consensus. ${ }^{17} \mathrm{All}$ conclusions must be agreed upon by the Arctic Council, following a thorough process of proposal vetting and agreement by all member governments. The requirement of consensus protects member nations from being forced to impose policies on which they disagree. ${ }^{18}$

The work of the Arctic Council focuses on two main objectives: environmental protection, and sustainable development. The Council does not, however, address military security issues. To accomplish these goals, the Council has authorized several cooperative activities to be conducted largely through six working groups: the Arctic Monitoring and Assessment Program (AMAP); Conservation of Arctic Flora and Fauna (CAFF); Protection of

\footnotetext{
${ }^{15}$ Evan T Bloom, "Establishment of the Arctic Council." American Journal of International Law 93, no. 3, July 1999, 712-22, https://doi.org/10.2307/2555272.

${ }^{16}$ Oran R Young. "Whither the Arctic? Conflict or cooperation in the circumpolar north." Polar record 45, no. 1 (2009): 73-82. Accessed November 10, 2021. https:/www.cambridge.org/core/journals/polar-record/article/abs/whither-the-arctic-conflict-or-cooperation-in-the-ci rcumpolar-north/DE469EF04C893CABA8CEB3C29C52542B.

${ }^{17}$ Stokke, Olav Schram, and Geir Hønneland, eds. International cooperation and Arctic governance: regime effectiveness and northern region building, Vol. 50 (Routledge, 2006).

${ }^{18}$ See note 14.
} 
the Arctic Marine Environment (PAME); Emergency Prevention, Preparedness and Response (EPPR); Sustainable Development Working Group (SDWG), and the Arctic Contaminants Action Program (ACAP).

The Arctic Council enables interactions between the Arctic states, non-Arctic states, and non-state actors. The Council's flexible soft-law framework has already made it possible for Indigenous Peoples to be included as Permanent Participants and has permitted non-Arctic countries to participate, particularly in the Working Groups as Observers ${ }^{19}$

\section{Observer Status}

The Arctic Council's “Rules of Procedures,” adopted in 1998 and revised in 2013, define the role of Observers. "Observer" means an entity as described in Article $3^{21}$ of the Ottawa Declaration which has been granted Observer status in accordance with these Rules. The primary role of Observers is to observe the work of the Arctic Council. Observers contribute through their engagement in the Arctic Council primarily at the level of working groups. The Observers are allowed to make statements only after the Arctic States and Permanent Participants, submit written statements, provide pertinent documents, and express their views on the matters under consideration. Observers may submit projects through an Arctic State or a Permanent Participant, but the overall financial contributions of all Observers is limited as these states cannot contribute more to a specific project than the Arctic States.

\footnotetext{
${ }^{19}$ Klaus J Dodds, “Anticipating the Arctic and the Arctic Council: pre-emption, precaution and preparedness," Polar Record 49, no. 2 (2013): 193-203, https://doi.org/10.1017/S0032247412000198.

${ }^{20}$ Arctic Council Rules of Procedure, Arctic Council, 1998, Accessed September 9, 2021, https://oaarchive.arctic-council.org/bitstream/handle/11374/1783/EDOCS-3688-v2-ACMMUS02_BARROW_2000 6 SAO Report to Ministers Annex1 Rules of Procedure.pdf? sequence $=1$.

${ }^{21}$ Observer status in the Arctic Council is open to: (a) non-Arctic states; (b) inter-governmental and inter-parliamentary organizations, global and regional; and (c) non-governmental organizations that the Council determines can contribute to its work.
} 
Since its inception, the Arctic Council has been open to Observers that are non-Arctic states that can be potentially accepted bi-annually during Arctic Council Ministerial Meetings (see Figure 1). Canada hosted the first meeting of the Council in 1998 when the first wave of non-Arctic Observer states was admitted via the Iqaluit Declaration. ${ }^{22}$

Figure 1. Admittance of Observer Non-Arctic states to Arctic Council.

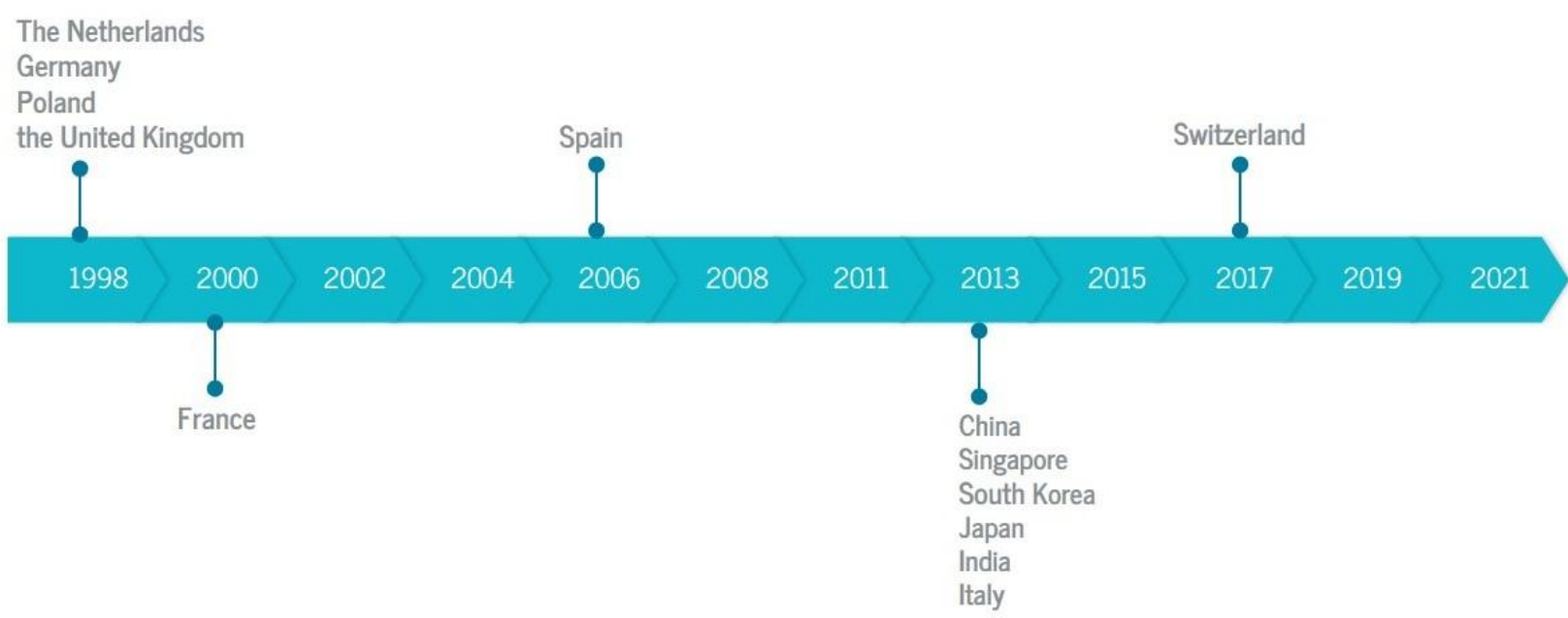

According to the "Arctic Council Rules of Procedure," Observers are accepted if they fulfill a set of criteria determined by the Arctic Council (see Table 1). ${ }^{23}$ The Observers need to have the political willingness and the financial ability to contribute to the work of the Arctic Council. Observers are asked to inform the Chairmanship about their activities and their contributions to the work of the Arctic Council. Rules of procedures also stipulate that Observer status shall be reviewed at the ministerial meetings every four years, from the date of granting of Observer status.

\footnotetext{
${ }^{22}$ The Iqaluit Declaration, Arctic Council, 1998, Accessed 14 September 14, 2021, https://oaarchive.arctic-council.org/handle/11374/86.

${ }^{23}$ See note 19.
} 
Table 1: Criteria for admitting Observers to Arctic Council

\begin{tabular}{|l|l|}
\hline Observer & Description \\
\hline Accepts and & The objectives of the Arctic Council as defined in the Ottawa Declaration. \\
\hline Recognizes & $\begin{array}{l}\text { The Arctic states' sovereignty, sovereign rights, and jurisdiction in the Arctic, } \\
\text { and an extensive legal framework applied to the Arctic Ocean. }\end{array}$ \\
\hline Respects & $\begin{array}{l}\text { The values, interests, cultures, and traditions of Arctic Indigenous peoples } \\
\text { and other Arctic inhabitants. }\end{array}$ \\
\hline Demonstrates & $\begin{array}{l}\text { A political willingness, as well as a financial ability, to contribute to the work } \\
\text { Interests and expertise relevant to the work of the Arctic Council. } \\
\text { An ability to support the work of the Arctic Council, including through } \\
\text { partnerships with member states and Permanent Participants }\end{array}$ \\
\hline
\end{tabular}

Source: Arctic Council Rules of Procedure, Annex 2

\section{First wave of Observer States 1998-2006}

The first Observer states to join the Arctic Council were the United Kingdom, Germany, Poland, and the Netherlands. Germany, Poland, and the United Kingdom served as Observers in the Arctic Environmental Protection Strategy (AEPS) ${ }^{24}$ formed in 1991, which was the predecessor to the Arctic Council. These states have some of the largest polar region research programs and allocate substantial funding to Arctic research. For instance, the UK hosts the British Antarctic Survey (BAS) which manages Natural Environment Research Council (NERC) funded polar research stations in the Antarctic and Arctic. With an annual budget of around $£ 50$

\footnotetext{
${ }^{24}$ Arctic Environmental Protection Strategy, 1991. Accessed 6, August 2021. http://library.arcticportal.org/1542/1/artic environment.pdf.
} 
million, the BAS is a significant player in the Arctic and Antarctic. ${ }^{25}$ Additionally, it operates two modern ice-strengthened research ships, a fleet of specially adapted planes, and a variety of commercially available and specialized vehicles. Poland established research facilities on Svalbard as early as the 1950s (as a result of Poland's accession to the Spitsbergen Treaty) and the country has been active in Arctic environmental cooperation since its inception in the early $1990 s^{26}$

France became an Observer state in 2000 and has a long history of Arctic research. Spain was accepted as an Observer to the Arctic Council in 2006. Unlike Germany, the United Kingdom, and France, Spain lacked a lengthy history of scientific exploration in the Arctic region. Spain's interest in the region has resurfaced as a result of global warming, the threat of rising sea levels, and the prospect of gaining access to the territory's natural resources. ${ }^{27}$

Admittance of Germany, Poland, and the United Kingdom as Observers to the AC from a signalling perspective was predictable since these countries were Observers in the work of the AEPS. The expansion of Observers by the admittance of France and Spain showed a willingness to expand the $\mathrm{AC}$ to the biggest $\mathrm{EU}$ countries with clear Arctic agendas.

\section{Second wave of Observer States 2013-2017}

The second wave of Observer admittance started in 2013 when six non-Arctic states were accepted. These were China, South Korea, Singapore, Japan, India, and Italy. The acceptance of

\footnotetext{
${ }^{25}$ The British Antarctic Survey, Accessed September 1, 2021 https://www.bas.ac.uk/about/about-bas/our-organisation/.

${ }^{26}$ Piotr Graczyk, "Poland and the Arctic: Between science and diplomacy," Arctic Yearbook (2012); Graczyk, Piotr, "Poland and the Arctic: Between Science and Diplomacy," Accessed November 15, 2021, https://arcticyearbook.com/arctic-yearbook/2012/2012-scholarly-papers/14-poland-and-the-arctic-between-science-a nd-diplomacy.

${ }^{27}$ Natalia M Antyushina, "Newcomers of the Arctic Council Open the Far North," Arctic and North 24 (October 1, 2016): 71-84, https://doi.org/10.17238/issn2221-2698.2016.24.80.
} 
East Asian states has been stipulated by their increasing commercial interest and shipping capabilities in the Arctic, and by their involvement in broader global issues like climate change. According to Mia Bennet, the involvement of a country like Singapore, despite its physical distance from the Arctic region, was possible due to the globalization of the Arctic economy, the move from national to global governance, and the development of the Arctic region as an investment frontier. ${ }^{28}$ These observers have, for example, had research stations on Svalbard, have developed their ice-breaker fleet and other polar-related technologies. Prior to its admittance to the Arctic Council, the Japanese government established task forces and working groups to foster a better understanding of the region and the countries' existing activities in the Arctic. Japan made its first application for Observer status in $2009 .{ }^{29}$ Bilateral cooperation has occurred, for example, by linking resources in the North Pacific and wider Arctic region to destinations in Northeast Asia via the shipping lanes of the Northern Sea Route. ${ }^{30}$

From a signalling perspective, the decision to include Northeast Asian countries opened up the Arctic Council to multilateralism, presented the forum to a much broader audience, and piqued interest in the Council's work from the global perspective. The admission of these states coincided with updated admission criteria for Observers and an introduction of the Observer Manual for Subsidiary Bodies, which defined the structure and procedure of the Arctic Council. ${ }^{31}$ The Manual defined who sits where and in what order statements can be contributed, as well as

\footnotetext{
${ }^{28}$ Mia M Bennett, "Singapore: The "global city" in a globalizing Arctic." Journal of Borderlands Studies 33, no. 2 (2018): 289-310. https://doi.org/10.1080/08865655.2017.1367708.

${ }^{29}$ Yoko Kamikawa and Hamachi Tomoko, "Japan's Evolving Efforts toward Sustainable Development of the Arctic | Science \& Diplomacy,” Accessed October 7, 2021, https://www.sciencediplomacy.org/perspective/2016/japans-evolving-efforts-toward-sustainable-development-arctic.

${ }^{30}$ Mia M Bennett, "North by Northeast: toward an Asian-Arctic region," Eurasian Geography and Economics 55, no. 1 (2014): 71-93, https://doi.org/10.1080/15387216.2014.936480.

${ }^{31}$ Arctic Council Observer Manual for Subsidiary Bodies, Arctic Council, 2013, Accessed September 11, 2021, https://oaarchive.arctic-council.org/handle/11374/939.
} 
the financial contributions of Observers to the work of the Arctic Council. From the Canadian perspective, Canada's decision to admit East Asian states as Observers in the Arctic Council was driven by the prospect of economic benefits from the involvement of Asian countries in Canada's North. ${ }^{32}$ Even so, the presence of East Asian countries in the work of the Arctic Council generated anxiety over national interests, sovereignty issues, and drew a lot of media and research attention. ${ }^{33}$ After admission to the Arctic Council, the East Asian Observer states developed their Arctic strategies to further advance and legitimize their involvement in the region. In the same round of Observer state applications in 2013, the EU's application was unsuccessful, namely the Arctic Council "receive[d] the application of the EU for Observer status affirmatively," but deferred a final decision. Until such time as Ministers of the Arctic States may reach a final decision, the EU may observe Council proceedings. ${ }^{34}$ The EU had already attempted to apply for the Observer status in 2008 but was blocked by Canada in response to the EU regulation banning the trade of seal products. ${ }^{35}$

In 2017, Greece, Turkey, Switzerland, and Mongolia, applied for Observer status. Of these four, only Switzerland was accepted. In its application, Switzerland stated that, like India, it has geographic similarities to the Arctic because of its mountains and glaciers that are melting. Switzerland stressed the importance of its efforts on climate change and on the reduction of pollutants of chemical origin, which are vital to the Arctic. ${ }^{36}$

${ }^{32}$ P. Whitney Lackenbauer, "Canada and the Asian observers to the Arctic Council: Anxiety and opportunity," Asia Policy 18, no. 1 (2014): 22-29.

${ }^{33}$ Julie Babin and Frederic Lasserre, "Asian states at the Arctic Council: perceptions in Western States," Polar Geography 42, no. 3 (2019): 145-159, https://doi.org/10.1080/1088937X.2019.1578290.

${ }^{34}$ Observers, Arctic Council, 1998, Accessed September 9, 2021, https://arctic-council.org/about/observers/

${ }^{35}$ Fernando Garcés de los Fayos, "The Outcome of the Ninth Arctic Council Ministerial Meeting," (2015).At A Glance. Brussels: European Parliament, Directorate-General for External Policie. Accessed November 27, 2021. https://www.europarl.europa.eu/RegData/etudes/ATAG/2015/549036/EXPO_ATA(2015)549036_EN.pdf.

${ }^{36}$ Yereth Rosen, "From the south, keen interest in the Arctic and the Arctic Council," Arctic Today, May 15, 2017, https://www.arctictoday.com/from-the-south-keen-interest-in-the-arctic-and-the-arctic-council. 
This marked the end of the second wave of Observers' admittance. In a 2016 interview with The Barents Observer, US Senior Arctic Official Julie Gourley, commented on the discussions regarding the development and future of admittance to the Arctic Council by stating that, "It's getting to be a very large, crowded room. And we're kind of hitting, in some respects, capacity." ${ }^{37}$ The absence of justification for the rejection of the applications made by Greece, Turkey, and Mongolia due to consensus-based format created a fuzzy signal, meaning that the signal creates more uncertainty due to vagueness and incomplete information.

\section{Unsuccessful Observer Applications in 2021}

In 2021, formal applications for seeking Observer status were made by Ireland, Estonia, and the Czech Republic. In its application, the Czech Republic (Czechia) stated that while it is located in Central Europe, it is connected to the Arctic through its highest mountains. ${ }^{38}$

Moreover, the Czech Republic outlined that it fully supports the goals and objectives of the Arctic Council, as defined in the Ottawa Declaration. ${ }^{39}$ In 2020 the Czech Republic announced that it would like to propose itself as a country involved in finding solutions to climate change by leveraging the accomplishments of its scientists and it has capabilities to do so, such as by having a research base on the Norwegian archipelago of Svalbard. ${ }^{40}$

At a webinar hosted by the Institute for International and European Affairs and the Department of Foreign Affairs in March 2021, Ireland's Minister of Foreign Affairs Simon

\footnotetext{
${ }^{37}$ Yereth Rosen, "How many observers can the Arctic Council handle?" The Barents Observer, March 16, 2016. https://thebarentsobserver.com/ru/node/582.

${ }^{38}$ Ministry of Foreign Affairs of the Czech Republic, "Czechia on Its Way to Achieving Arctic Council Observer Status," Accessed August 17, 2021. https://www.mzv.cz/file/4247197/Czechia in the Arctic The Arctic in Czechia.pdf ().

${ }^{39}$ Marc Lanteigne, "Centre-to-North: The Arctic Policies of the Czech Republic" Overthecircle, March 28, 2021, https://overthecircle.com/2021/03/28/centre-to-north-the-arctic-policies-of-the-czech-republic/.

40 "Deník N: Czech government to consider applying for membership in Arctic Council," Radio Prague International, September 16, 2020, https://english.radio.cz/denik-n-czech-government-consider-applying-membership-arctic-council-8692258.
} 
Coveney introduced Ireland's application for Observer status to the Arctic Council. Ireland's interest in the melting Arctic ice and its application for Observer status in the Arctic Council is viewed as an extension of multilateralism at the heart of Irish foreign policy. Ireland's application focused on three core pillars through which it would add value to the work of the Arctic Council. Firstly, policy and scientific capacity; secondly, experience as a proactive global actor; thirdly, empowering vulnerable communities. ${ }^{41}$

Before its application submission, Estonia organized an event entitled: "Estonia as an Aspiring Arctic Council Observer State" and The Ministry of Foreign Affairs hosted a thematic Arctic Month, which ran from January 28th to February 28th, 2021. Estonia emphasized its location as the most northern EU country that is not in the Arctic but is immediately impacted by Arctic trends. Estonia offered to contribute to the Arctic's sustainable development through its knowledge, extensive experience in polar research, and innovative approach.

Despite elaborate applications and social media campaigns, none of these applicants were successful in receiving Observer status. Since the decision is made by consensus and is not elaborated upon, this non-admittance can be interpreted as a signal of unwillingness to further expand the Arctic Council. Military security concerns could have been evident in the case of the Arctic Council expansion with Estonia and the Czech Republic which are both member states to NATO. Coffey and Kochis propose that as a NATO partner, the US should firmly support Estonia's proposal to join the Arctic Council as an Observer. ${ }^{42}$ Ireland on the other hand is not a NATO member state and is considered NATO's “neutral" partner together with Sweden, Finland,

\footnotetext{
${ }^{41}$ Government of Ireland, "Ireland's application for Arctic Council Observer Status," Accessed August 11, 2021, https://assets.gov.ie/125514/c51224dc-2006-410c-af2e-c39c712be909.pdf.

${ }^{42}$ Luke Coffey and Daniel Kochis, "Why the U.S. Should Support Arctic Council Observer Status for Estonia" The Heritage, January 19, 2021, https://www.heritage.org/global-politics/report/why-the-us-should-support-arctic-council-observer-status-estonia.
} 
Switzerland, and Austria that also have a "neutrality" status. However, in 1999, Ireland joined NATO's Partnership for Peace (PfP) programme and the Euro-Atlantic Partnership Council, a multilateral forum for dialogue which brings together all Allies and partner countries in the Euro-Atlantic area. ${ }^{43}$

There has not been much commentary delivered on the decisions made by the Arctic Council to reject Observers' applications. A public relations officer for the Arctic Council told Estonian News: "There were no new Observers admitted to the Council. The Arctic Council is a consensus-based forum, and consensus was not reached on Observer applications at that time. As this is a closed decision, we cannot comment beyond the consensus - or non-consensus - that was or was not reached. ${ }^{\circ 4}$ Poland, one of the current Observers, remarked in its Statement to the 12th Ministerial Meeting of the Arctic Council that "we are of the view that when, hopefully, the Council takes the decision to admit on the basis of appropriate applications further Observer states, the Council itself will benefit from the knowledge, experience and commitment of those countries, which will be beneficial for the whole Arctic community." ${ }^{45}$ Poland as an Observer can comment in its statement but does not decide. The decision by consensus for admitting Observers rests only within the Arctic states.

What type of signal does the rejection of the Observer application send to the rest of the world? This can be interpreted as a time out for expanding the forum in wake of changing geopolitical situations with tensions in East-West relationships, the growing concerns for

43 “Relations with Ireland,” NATO, April 6, 2021, https://www.nato.int/cps/en/natohq/topics 51979.htm.

44 "Estonia's bid for Arctic Council observer status unsuccessful," ERR News, June 22, 2021, https://news.err.ee/1608254889/estonia-s-bid-for-arctic-council-observer-status-unsuccessful.

${ }^{45}$ Statement of Poland to the $12^{\text {th }}$ Ministerial Meeting of the Arctic Council, Accessed November 5, 2021, https://oaarchive.arctic-council.org/bitstream/handle/11374/2681/MMIS12 2021_REYKJAVIK Observer-Statemen t State Poland.pdf? sequence $=1$ \&isAllowed $=\mathrm{y}$. 
militarization of the Arctic, and increasing demand for the development of Arctic resources. The signal is fuzzy as none of the countries that applied, despite their differences, met an "ideal" candidate profile in order to be accepted in a consensus-based decision process.

\section{After the Reykjavik Ministerial}

The Estonian MEP Urmas Paet expressed the need to address security issues in the Arctic. According to Urmas Paet, the Arctic has thus far been a peaceful area of international cooperation. However, Paet also said that "At the same time, the actions of two authoritarian states - China and Russia - there cause wariness. Russia is militarizing its Arctic regions, and China has begun efforts to strengthen its position in the Arctic with a view to becoming a polar force." ${ }^{46}$ Later in the year, in August 2021, The Barents Observer newspaper reported that Russia expelled the Estonian consul with a claim over him seeking sensitive information about Russia's Arctic policy. ${ }^{47}$ In June 2021, Ireland introduced the Nordic strategy aiming to strengthen Ireland's bilateral and multilateral relations with Denmark, Finland, Iceland, Norway, and Sweden ${ }^{48}$ The strategy will increase cooperation with Nordic countries, particularly on climate change. It will be evident in two years' time if the same countries re-apply for the Observer status. The uncertainty generated by fuzzy signalling can contribute to the willingness to apply again.

46 "Estonian MEP: EU must focus on rapid changes taking place in Arctic", The Baltic Times, July 6, 2021. https://www.baltictimes.com/estonian mep eu must focus on rapid changes taking_place in arctic/.

${ }^{47}$ Thomas Nislen, " Russia spy agency says expelled Estonian consul was interested in Arctic plans", The Barents Observer, August 06, 2021.

https://thebarentsobserver.com/en/arctic/2021/08/expelled-estonian-consul-supposedly-showed-interest-russias-arcti c-plans.

${ }^{48}$ Kevin O'Sullivan, "Ireland's Nordic strategy to deepen cooperation on climate and energy", The Irish Times, June 2, 2021.

https://www.irishtimes.com/news/politics/ireland-s-nordic-strategy-to-deepen-co-operation-on-climate-and-energy-1 .4582390 . 


\section{Signals for Future Observer States}

Analysis of three waves of Observer states' acceptance to the AC reveals changing trends from expansion and internalization to an unwillingness to admit new non-Arctic Observer states. Unsuccessful applications in 2021 to the AC create fuzzy signals to other prospective Observer states wishing to apply to the AC. The signals suggest that there is no certain and straightforward way to obtain an Observer status. Applications from Estonia, Ireland, and the Czech Republic would formally tick all the boxes, but disagreements among the Arctic states meant that no consensus was achieved. Interpreting signals from a consensus-based intergovernmental forum such as the AC is not easy as signalling is fuzzy and does not follow the same logic as national states operating in the domain of costly signals. Negotiating and bargaining in foreign politics becomes more complex when multiple actors are involved due to divergences in state preferences and alliance dynamics. ${ }^{49}$ While military aspects are off limits in the work of the AC, the changing geopolitical environment shall be examined in order to place signalling on the Observers admittance in the context. Additionally, the admittance of Observer states follows a fuzzy logical progression ${ }^{50}$ when little is known about policy outcomes, political values, and how likelihoods of pros and cons of Observers admittance are estimated by decision-makers behind closed doors.

Research has highlighted that there is a noticeable disconnect between Observers states goals and reality, and few empirical examples mitigate the fact that "the Arctic Council has not

\footnotetext{
${ }^{49}$ Max Gallop, "More dangerous than dyads: bargaining and war in multi-actor disputes," Journal of Theoretical Economics (2017), Accessed November 10, 2021, https://core.ac.uk/download/pdf/77033401.pdf.

${ }^{50}$ Claudio A Cioffi-Revilla, "Fuzzy Sets and Models of International Relations," American Journal of Political Science 25, no. 1 (1981): 129-59, https://doi.org/10.2307/2110917.
} 
been able to integrate non-Arctic experts into its projects as efficiently as possible." ${ }^{\circ 1}$ According to Sebastian Knecht, Observers contribute only to every fifth project (26 out of a total of 125 projects). Among the five new Asian Observers, Japan has contributed to six, China and South Korea to five, and India and Singapore each to two projects. Observers participate at Arctic Ministerial and Senior Arctic Officials (SAO) meetings, where procedural rules grant them few participatory rights. ${ }^{52}$ Researchers have brought attention to the "club-like" nature of the AC, which faces the decision of retaining exclusivity for the current members or incorporating new members in light of changing circumstances. Allowing newcomers into clubs might diminish the relative privileges of existing members, while keeping the club closed is detrimental to its efficacy and legitimacy. ${ }^{53}$

Recommendations to rejuvenate the Arctic Council introduced in 2016 by Heather Conley and Matthew Melino brought forward difficulties to reform the Arctic Council due to its consensus-based nature. ${ }^{54}$ If the Arctic Council continues operating in the same manner and does not admit new Observer states, from a strategic view it can be viewed as "deferred maintenance." ${ }^{55}$ At the $12^{\text {th }}$ Ministerial Meeting the Arctic Council revealed its Strategic Plan for 2021 to 2030. The plan aspires to "enhance constructive, balanced, and meaningful Observer engagement and

\footnotetext{
${ }^{51}$ Paula Kankaanpää, "The Arctic Council-from knowledge production to influencing Arctic policy making," The Yearbook of Polar Law Online 4, no. 1 (2012): 59-76.

${ }^{52}$ Sebastian Knecht, "The Arctic Council, Asian Observers and the Role of Shadow Networks in the Science-Policy Interface," in 'Observing' the Arctic; Asia in the Arctic Council and Beyond, Chih Y. Woon and Klaus Dodds (eds.). 2020. Cheltenham: Edward Elgar Publishing. https://doi.org/10.4337/9781839108211.00008

${ }^{53}$ Matthew D Stephen and Kathrin Stephen, "The integration of emerging powers into club institutions: China and the Arctic Council," Global Policy 11 (2020): 51-60, https://doi.org/10.1111/1758-5899.12834.

${ }^{54}$ Heather A Conley and Matthew Melino, "An Arctic redesign: Recommendations to rejuvenate the Arctic council” Center for Strategic \& International Studies, 2016, Accessed 10 September, http://csis-website-prod.s3.amazonaws.com/s3fs-public/legacy files/files/publication/160302 Conley ArcticRedesi gn Web.pdf.

${ }^{55}$ See note 49.
} 
encourage their proactive engagement in relevant activities of the Council." ${ }^{96}$ The plan does not mention anything about the Council's position towards expanding the number of Observers. The countries that would like to apply for the Observer status need to review the past and present work of the Council and anticipate future geopolitical forces that might influence a consensus-based decision. In 2023, at the end of the Russian Chairmanship, there will already be some evidence on the strategic plan of implementation, and it will be known how many new aspiring Observers line up at the door of the Arctic Council.

${ }^{56}$ Arctic Council Strategic Plan 2021 to 2030, Accessed 12 September, 2021, https://oaarchive.arctic-council.org/bitstream/handle/11374/2601/MMIS12_2021_REYKJAVIK_Strategic-Plan_202 1-2030.pdf? sequence $=1$ \&isAllowed $=\mathrm{y}$. 


\section{Bibliography}

Antyushina, Natalia M. "Newcomers of the Arctic Council Open the Far North." Arctic and North 24 (October 1, 2016): 71-84. https://doi.org/10.17238/issn2221-2698.2016.24.80.

Arctic Council Observer Manual for Subsidiary Bodies. Arctic Council, 2013. Accessed September 11, 2021. https://oaarchive.arctic-council.org/handle/11374/939.

Arctic Council Rules of Procedure. Arctic Council, 1998. Accessed September 9, 2021.https://oaarchive.arctic-council.org/bitstream/handle/11374/1783/EDOCS-3688-v 2-ACMMUS02_BARROW_2000_6_SAO_Report_to_Ministers_Annex1_Rules_of_Pr ocedure.pdf?sequence $=1$.

Arctic Council Strategic Plan 2021 to 2030. Accessed 12 September, 2021. https://oaarchive.arctic-council.org/bitstream/handle/11374/2601/MMIS12_2021_REY KJAVIK_Strategic-Plan_2021-2030.pdf?sequence=1\&isAllowed=y.

Arctic Environmental Protection Strategy (1991). Available at:

http://library.arcticportal.org/1542/1/artic environment.pdf (Accessed: 6 August 2021).

Babin, Julie, and Frederic Lasserre. "Asian States at the Arctic Council: Perceptions in Western States.” Polar Geography 42, no. 3 (July 3, 2019): 145-59. https://doi.org/10.1080/1088937X.2019.1578290.

Bennett, Mia M. "North by Northeast: toward an Asian-Arctic region." Eurasian Geography and Economics 55, no. 1 (2014): 71-93. https://doi.org/10.1080/15387216.2014.936480.

Bennett, Mia M. "Singapore: The "global city" in a globalizing Arctic." Journal of Borderlands Studies 33, no. 2 (2018): 289-310. https://doi.org/10.1080/08865655.2017.1367708.

Biermann, Frank, and Philipp Pattberg. "Global environmental governance: Taking stock, moving forward." Annual Review of Environment and Resources 33 (2008): 277-294. https://doi.org/10.1146/annurev.environ.33.050707.085733.

Bloom, Evan T. "Establishment of the Arctic council." American Journal of International Law 93, no. 3 (1999): 712-722. https://doi.org/10.2307/2555272. 
Busch, Aslak Veierud. "Tall Tales from the High North: Contested Discourses of the Arctic as a Political Space." Geopolitics (2021): 1-27. https://doi.org/10.1080/14650045.2021.1963956.

Cioffi-Revilla, Claudio A. "Fuzzy sets and models of international relations." American Journal of Political Science (1981): 129-159. https://doi.org/10.2307/2110917.

Conley, Heather A., and Matthew Melino. An Arctic redesign: Recommendations to rejuvenate the Arctic council. Center for Strategic \& International Studies, 2016. Accessed 10 September, http://csis-website-prod.s3.amazonaws.com/s3fs-public/legacy files/files/publication/1 60302 Conley_ArcticRedesign_Web.pdf.

Coffey, Luke and Daniel Kochis., "Why the U.S. Should Support Arctic Council Observer Status for Estonia". The Heritage Foundation. January 19, 2021.

https://www.heritage.org/global-politics/report/why-the-us-should-support-arctic-counc il-observer-status-estonia.

de los Fayos, Fernando Garcés. "The Outcome of the Ninth Arctic Council Ministerial Meeting." (2015). At A Glance. Brussels: European Parliament, Directorate-General for External Policie. Accessed November 27, 2021. https://www.europarl.europa.eu/RegData/etudes/ATAG/2015/549036/EXPO_ATA(201 5)549036 EN.pdf.

Dodds, Klaus J. "Anticipating the Arctic and the Arctic Council: pre-emption, precaution and preparedness." Polar Record 49, no. 2 (2013): 193-203. https://doi.org/10.1017/S0032247412000198.

"Deník N: Czech government to consider applying for membership in Arctic Council". Radio Prague International. September 16, 2020.

https:/english.radio.cz/denik-n-czech-government-consider-applying-membership-arcti c-council-8692258.

Fearon, James D. "Signaling foreign policy interests: Tying hands versus sinking costs." Journal of Conflict Resolution 41, no. 1 (1997): 68-90. https://doi.org/10.1177/0022002797041001004.

Fuhrmann, Matthew, and Todd S. Sechser. "Signaling Alliance Commitments: Hand-Tying and Sunk Costs in Extended Nuclear Deterrence." American Journal of Political Science 58, no. 4 (2014): 919-935. Accessed November 14. 2021. https://www.jstor.org/stable/24363534. 
Gallop, Max. "More dangerous than dyads: bargaining and war in multi-actor disputes." Journal of Theoretical Economics (2017). Accessed November 10, 2021. https://core.ac.uk/download/pdf/77033401.pdf.

Gartzke, Erik A., Shannon Carcelli, J. Andres Gannon, and Jiakun Jack Zhang. "Signaling in foreign policy." In Oxford Research Encyclopedia of Politics. 2017.

Goldsmith, Jack L., and Eric A. Posner. "Moral and legal rhetoric in international relations: a rational choice perspective." The Journal of Legal Studies 31, no. S1 (2002): S115-S139. https://doi.org/10.1086/340087.

Government of Ireland. “ Ireland's application for Arctic Council Observer Status”. Accessed August 11, 2021. https://assets.gov.ie/125514/c51224dc-2006-410c-af2e-c39c712be909.pdf.

Graczyk, Piotr. "Poland and the Arctic: Between science and diplomacy." Arctic Yearbook (2012). Accessed November 15, 2021.

https://arcticyearbook.com/arctic-yearbook/2012/2012-scholarly-papers/14-poland-andthe-arctic-between-science-and-diplomacy.

Graczyk, Piotr, and Timo Koivurova. "A new era in the Arctic Council's external relations? Broader consequences of the Nuuk observer rules for Arctic governance." Polar Record 50, no. 3 (2014): 225-236. https://doi.org/10.1017/S0032247412000824.

Jervis, Robert. Perception and misperception in international politics. Princeton University Press, 2017.

Kamikawa, Yoko, and Hamachi, Tomoko. Japan's Evolving Efforts toward Sustainable Development of the Arctic. Science and Diplomacy. AAAS Center for Science Diplomacy, 2016. Accessed October 7, 2021. https://www.sciencediplomacy.org/perspective/2016/japans-evolving-efforts-toward-su stainable-development-arctic.

Kankaanpää, Paula. "The Arctic Council-from knowledge production to influencing Arctic policy making." The Yearbook of Polar Law Online 4, no. 1 (2012): 59-76.

Knecht, Sebastian. "The Arctic Council, Asian Observers and the Role of Shadow Networks in the Science-Policy Interface." in 'Observing' the Arctic; Asia in the Arctic Council and Beyond, Chih Y. Woon and Klaus Dodds (eds.). 2020. Cheltenham: Edward Elgar Publishing. https://doi.org/10.4337/9781839108211.00008. 
Lackenbauer, P. Whitney. "Canada and the Asian observers to the Arctic Council: Anxiety and opportunity." Asia Policy 18, no. 1 (2014): 22-29. Accessed November 27, 2021. https://www.jstor.org/stable/24905272.

Coffey, Lukeand Daniel Kochis. "Why the U.S. Should Support Arctic Council Observer Status for Estonia”. The Heritage Foundation. January 19, 2021.

https://www.heritage.org/global-politics/report/why-the-us-should-support-arctic-counc il-observer-status-estonia.

Marc Lanteigne, "Centre-to-North: The Arctic Policies of the Czech Republic"

Overthecircle, March 28, 2021.:

https://overthecircle.com/2021/03/28/centre-to-north-the-arctic-policies-of-the-czech-re public/.

McCarthy, Daniel R., and Matthew Fluck. "The concept of transparency in International Relations: Towards a critical approach." European Journal of International Relations 23, no. 2 (2017): 416-440.

Ministry of Foreign Affairs of the Czech Republic. "Czechia on Its Way to Achieving Arctic Council Observer Status”. Accessed August 17, 2021.

https://www.mzv.cz/file/4247197/Czechia in the Arctic The Arctic in Czechia.pdf.

O’Sullivan, Kevin. Kevin O'Sullivan, “Ireland's Nordic strategy to deepen co-operation on climate and energy", The Irish Times, June 2, 2021.

https://www.irishtimes.com/news/politics/ireland-s-nordic-strategy-to-deepen-co-operat ion-on-climate-and-energy-1.4582390.

Rowe, Elana Wilson. "Analyzing frenemies: An Arctic repertoire of cooperation and rivalry." Political Geography 76 (2020): 102072.

https://doi.org/10.1016/j.polgeo.2019.102072.

Relations with Ireland. NATO. April 6. 2021.

https://www.nato.int/cps/en/natohg/topics 51979.htm.

Statement of Poland to the 12th Ministerial Meeting of the Arctic Council. Accessed August $11,2021$.

https://oaarchive.arctic-council.org/bitstream/handle/11374/2681/MMIS12_2021_REY $\underline{\text { KJAVIK Observer-Statement State Poland.pdf? sequence }=1 \& \text { isAllowed }=\mathrm{y}}$.

Stephen, Matthew D., and Kathrin Stephen. "The integration of emerging powers into club institutions: China and the Arctic Council." Global Policy 11 (2020): 51-60. https://doi.org/10.1111/1758-5899.12834. 
Stokke, Olav Schram, and Geir Hønneland, eds. International cooperation and Arctic governance: regime effectiveness and northern region building. Vol. 50. Routledge, 2006.

The British Antarctic Survey. Accessed September 1, 2021

https://www.bas.ac.uk/about/about-bas/our-organisation/.

The Iqaluit Declaration. "Arctic Council, 1998". Accessed 14 September 14, 2021. https://oaarchive.arctic-council.org/handle/11374/86.

Thomas Nislen, “ Russia spy agency says expelled Estonian consul was interested in Arctic plans", The Barents Observer, August 06, 2021.

https://thebarentsobserver.com/en/arctic/2021/08/expelled-estonian-consul-supposedlyshowed-interest-russias-arctic-plans.

Väätänen, Vesa, and Kaj Zimmerbauer. "Territory-network interplay in the co-constitution of the Arctic and 'to-be'Arctic states." Territory, Politics, Governance 8, no. 3 (2020): 372-389. https://doi.org/10.1080/21622671.2018.1559759.

Wheeler, Nicholas, and Ken Booth. "The security dilemma: Fear, cooperation, and trust in world politics.” Palgrave Macmillan, 2008.

Yereth Rosen, "From the south, keen interest in the Arctic and the Arctic Council," Arctic Today, May 15, 2017.

https://www.arctictoday.com/from-the-south-keen-interest-in-the-arctic-and-the-arctic-c ouncil.

Yereth Rosen, "How many observers can the Arctic Council handle?" The Barents Observer, March 16, 2016. https://thebarentsobserver.com/ru/node/582.

Young, Oran R. "Whither the Arctic? Conflict or cooperation in the circumpolar north." Polar record 45, no. 1 (2009): 73-82. Accessed November 10, 2021. https://www.cambridge.org/core/journals/polar-record/article/abs/whither-the-arctic-co nflict-or-cooperation-in-the-circumpolar-north/DE469EF04C893CABA8CEB3C29C52 $\underline{542 \mathrm{~B}}$. 